\title{
HOMOGENIZATION OF AN Al-Mg ALLOY AND ALLIGATORING FAILURE: INFLUENCE OF THE MICROSTRUCTURE
}

\author{
HOMOGENIZACIJA Al-Mg ZLITINE IN KROKODILJENJE: VPLIV \\ MIKROSTRUKTURE
}

\author{
Endre Romhanji, Tamara Radetić, Miljana Popović \\ University of Belgrade, Faculty of Technology and Metallurgy, Department of Metallurgical Engineering, Karnegijeva 4, \\ POB 35-03, 11120 Belgrade, Serbia \\ endre@tmf.bg.ac.rs
}

Prejem rokopisa - received: 2015-06-01; sprejem za objavo - accepted for publication: 2015-06-12

\author{
doi:10.17222/mit.2015.111
}

\begin{abstract}
In this study the influence of the microstructure of Al-5.1Mg-0.7Mn alloy on the propensity towards an alligatoring failure was evaluated. The morphology of the constituent particles appears to be the key factor, with dissolution and fragmentation of fibrous $\mathrm{Mg}$-Si-Sr and transformation of the $\mathrm{Al}_{6}(\mathrm{Fe}, \mathrm{Mn})$ into more compact shapes taking place at homogenization temperatures above $520^{\circ} \mathrm{C}$, contributing to improved ductility and diminished propensity towards alligatoring. Homogenization at temperatures below $500{ }^{\circ} \mathrm{C}$ gave rise to a non-uniform precipitation of the dispersoids. Such a microstructure favored localized slip that induced stress concentration at the grain boundaries and triggered grain boundary embrittlement.

Keywords: Al-Mg alloy, homogenization, microstructure, localized slip, alligatoring

V študiji je bil ocenjen vpliv mikrostrukture zlitine Al-5,1Mg-0,7Mn na pojav krokodiljenja. Izgleda, da je morfologija delcev ključna, ker sta raztapljanje in drobljenje vlaknastih $\mathrm{Mg}$-Si-Sr ter pretvorba $\mathrm{Al}_{6}(\mathrm{Fe}, \mathrm{Mn})$ v bolj kompaktne oblike, kar se dogaja med homogenizacijo pri temperaturah nad $520{ }^{\circ} \mathrm{C}$, prispevala $\mathrm{k}$ izboljšanju duktilnosti in k odpravi krokodiljenja. Homogenizacija pri temperaturah pod $500{ }^{\circ} \mathrm{C}$ povzroči povečanje neenakomernega izločanja delcev. Taka mikrostruktura pospešuje lokalno drsenje ki povzroči koncentracijo napetosti na mejah zrn in sproži pojav interkristalne krhkosti.

Ključne besede: zlitina Al-Mg, homogenizacija, mikrostruktura, lokalno drsenje, krokodiljenje
\end{abstract}

\section{INTRODUCTION}

Fabrication of high strength Al-Mg sheet products requires careful design of the thermo-mechanical process to avoid hot fracture. ${ }^{1}$ In the first part of this study, we report on the effect of homogenization temperature on failure by alligatoring during hot rolling of the Al-5.1Mg-0.7Mn alloy. ${ }^{2}$

Alligatoring has been studied mostly from the aspect of rolling process optimization ${ }^{1}$ while microstructural factors influencing the occurrence of alligatoring are far less understood. However, there is evidence that the microstructure contributes to a propensity to alligatoring. Cold rolling of spheroidized 1020, 1045 and 1090 steels failed due to the alligatoring only in the last alloy, which has greatest density and length of linear inclusions. ${ }^{3}$ Another study on a steel ${ }^{4}$ showed that the occurrence of the alligatoring was influenced by the presence of $\mathrm{MnS}$ inclusions. The high density of coarse Mn-based constitutive particles increased the susceptibility to alligatoring in $\mathrm{Al}-\mathrm{Mg}$ alloys. ${ }^{5}$

The aim of this work was to evaluate the effect of homogenization temperature and resultant microstructures on the occurrence of alligatoring in $\mathrm{Al}-5.1 \mathrm{Mg}-0.7 \mathrm{Mn}$ alloy during hot rolling experiments.

\section{EXPERIMENTAL WORK}

The Al-5.1Mg-0.7Mn alloy studied had higher $\mathrm{Mg}$ and $\mathrm{Zn}$ contents compared to the standard AA 5083 alloy. The exact chemical composition was given in ${ }^{2}$.

The industrial cast alloy was hot rolled in the laboratory. Prior to hot rolling, the plates were homogenized. Three homogenization regimes were applied, with a difference in the homogenization temperature. Regime I corresponded to the homogenization temperature of $460{ }^{\circ} \mathrm{C}$, Regime II to $520{ }^{\circ} \mathrm{C}$ and Regime III to $550{ }^{\circ} \mathrm{C}$. Details of the homogenization treatment and hot rolling procedure were given in ${ }^{2}$.

Microstructural characterization involved light microscopy and Scanning Electron Microscopy (SEM). Specimens were prepared by fine mechanical polishing of sections of interest. SEM characterization was conducted in JEOL JSM-6610LV at $20 \mathrm{kV}$ equipped with an Energy-Dispersive X-ray Spectroscopy (EDS) detector. Specimens for light microscopy were examined in the as-polished state and after electrolytic etching with Barker's reagent. 


\section{RESULTS}

\subsection{Microstructure around the alligator crack tip}

A cross-section of an alligator crack tip in the fractured plate interior is shown in Figure 1a. A number of cracks and micro-cracks was observed in its vicinity (Figures 1 and 1b). The micro-cracks were associated with a fracture (Figures 1c and 1d) of the constituent particles. The alligator crack propagated in the intergranular manner (Figure 2a), but some deviations, most likely following the slip bands, were observed.

In a number of grains, bands with coloration different from the surrounding matrix were observed (Figure 2b). Barker's etch has a sensitivity toward changes in the crystallographic orientation, so the bands were most likely slip bands introduced by intensive localized slip. The bands were present in plates homogenized at $460{ }^{\circ} \mathrm{C}$
(Regime I) and $520{ }^{\circ} \mathrm{C}$ (Regime II), but in the latter case they were finer and more evenly distributed.

\subsection{Microstructure}

Microstructure of the as-cast state consisted of constituent particles and Al matrix. ${ }^{6}$ Products of solidification, coarse constituent particles were mostly situated along the dendrite boundaries that, to a large extent, overlapped with grain boundaries. The constituent particles were identified as $\mathrm{Al}_{6}(\mathrm{Fe}, \mathrm{Mn}), \mathrm{Mg}_{2} \mathrm{Si}$ and $\mathrm{Mg}-\mathrm{Si}$ phase enriched in $\mathrm{Sr}$ ( $\mathrm{Sr}$ is present as a trace element in the alloy $)^{2,6}$ and $\mathrm{Al}_{6}(\mathrm{Fe}, \mathrm{Mn})$ phase with a Chinese script morphology. Thin, fibrous $\mathrm{Mg}$-Si-Sr phase with attached rectangular $\mathrm{Mg}_{2} \mathrm{Si}$ lined the grain boundaries. Homogenization induced rounding of the sharp facets of the constitutive particles. ${ }^{6}$

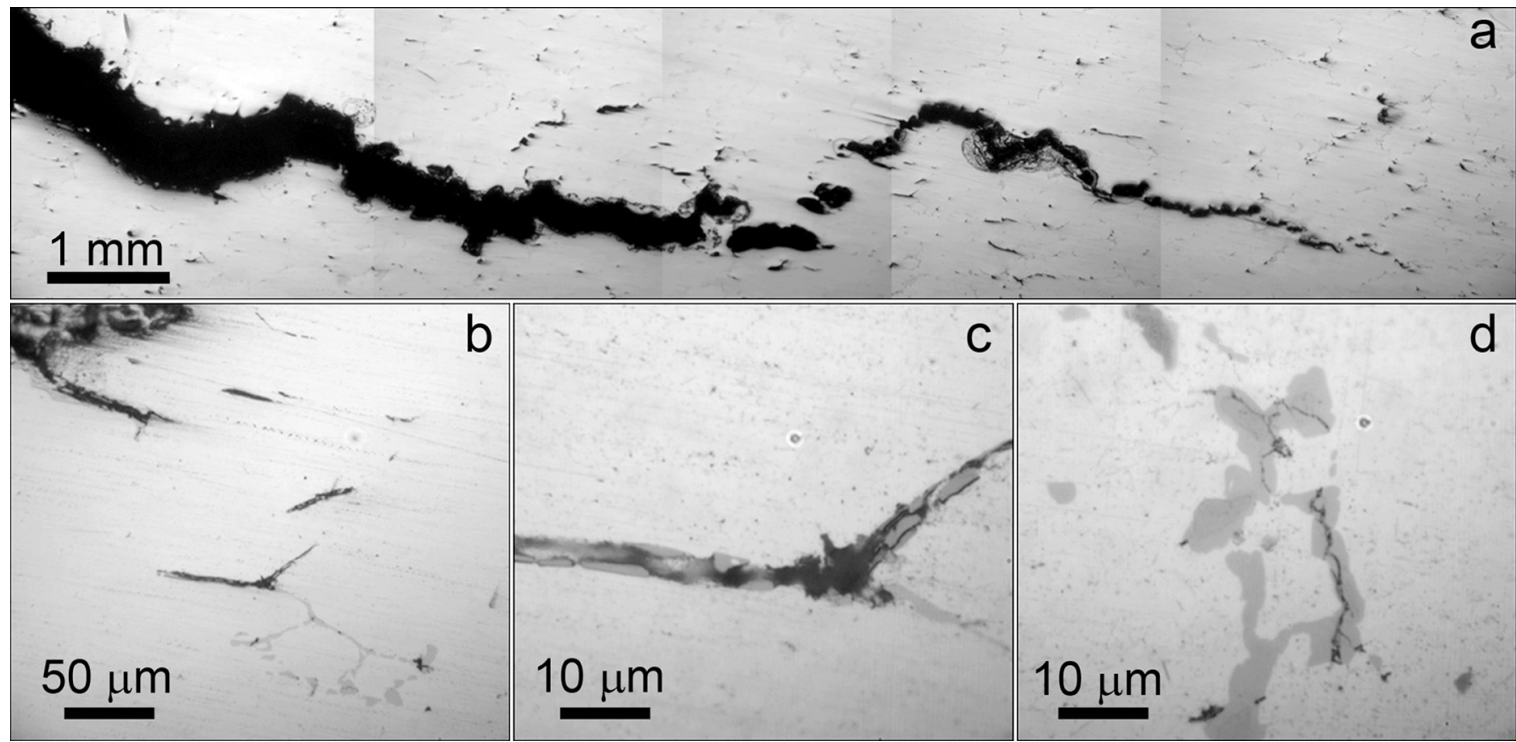

Figure 1: Light micrographs of: a) the tip of alligator crack, b) to d) microcracks and fractured constitutive particles in a plate homogenized at $460{ }^{\circ} \mathrm{C}$

Slika 1: Svetlobni posnetki: a) vrh krokodilje razpoke, od b) do d) mikrorazpoke in prelom delcev v plošči, homogenizirani pri $460{ }^{\circ} \mathrm{C}$
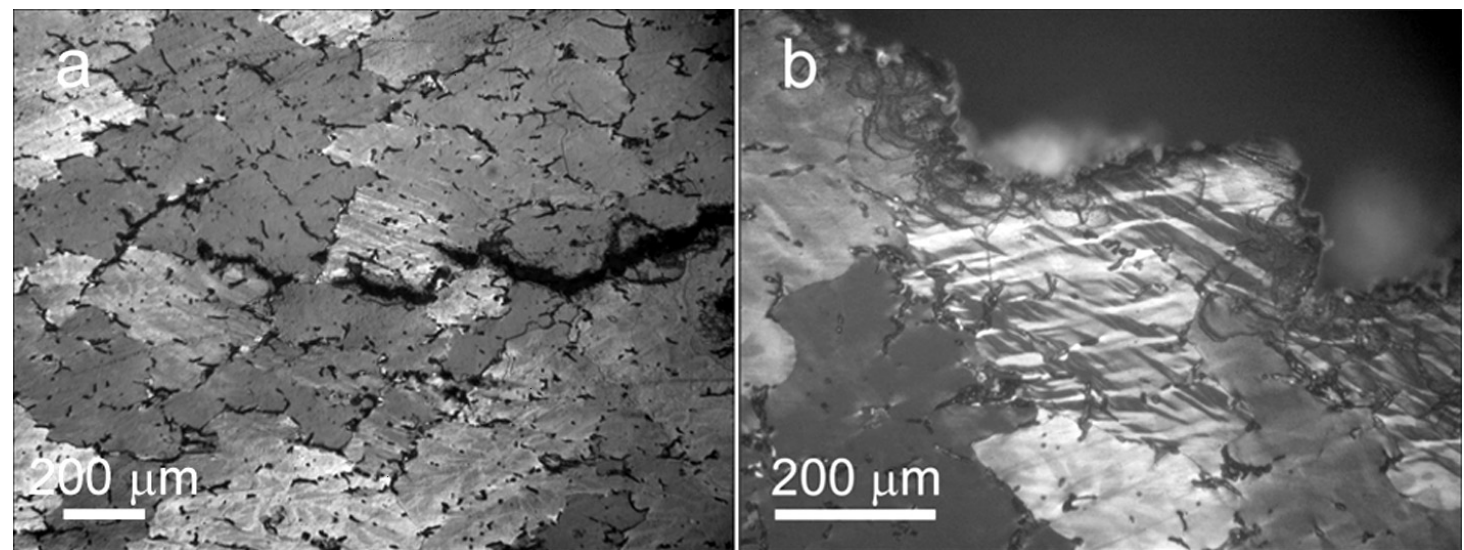

Figure 2: Light micrographs of the plates etched with Barkers' reagent: a) intergranular propagation of the alligator crack (homogenization at $520{ }^{\circ} \mathrm{C}$ - Regime II), b) slip bands (homogenization at $460{ }^{\circ} \mathrm{C}$ - Regime I)

Slika 2: Svetlobna posnetka plošče, jedkane z Barker jedkalom: a) napredovanje aligatorske razpoke med zrni (homogenizacija pri $520{ }^{\circ} \mathrm{C}$ Režim II), b) trakovi drsenja (homogenizacija pri $460{ }^{\circ} \mathrm{C}-$ Režim I) 


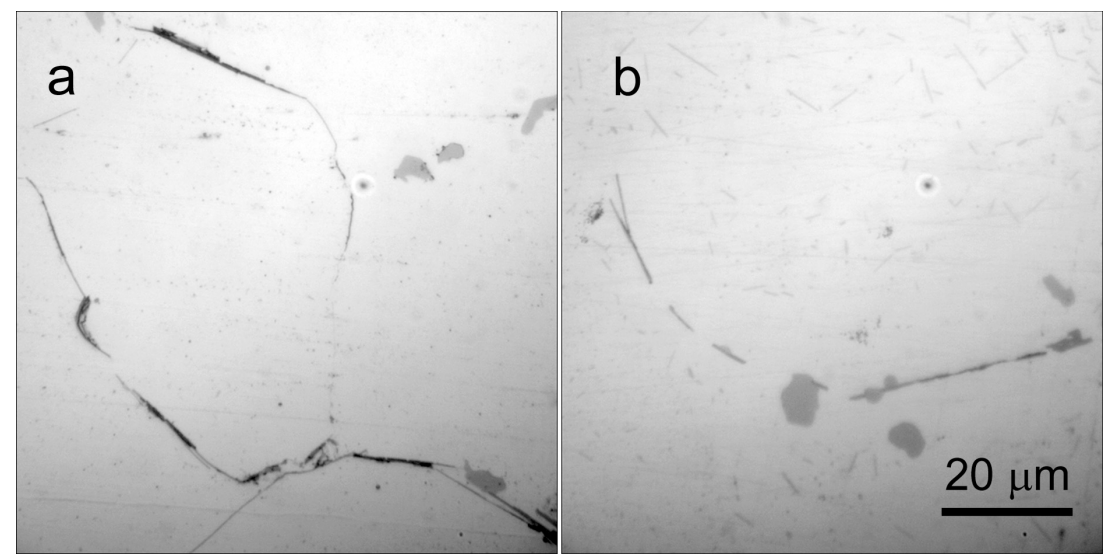

Figure 3: Light micrographs of the fibrous $\mathrm{Mg}-\mathrm{Si}-\mathrm{Sr} / \mathrm{Mg}_{2} \mathrm{Si}$ constitutive particles: a) $460{ }^{\circ} \mathrm{C}$ (Regime I), b) $550{ }^{\circ} \mathrm{C}(\mathrm{Regime}$ III) Slika 3: Svetlobna posnetka vlaknastih delcev $\mathrm{Mg}-\mathrm{Si}-\mathrm{Sr} / \mathrm{Mg}_{2} \mathrm{Si}:$ a) $460{ }^{\circ} \mathrm{C}$ (Režim I), b) $550{ }^{\circ} \mathrm{C}$ (Režim III)
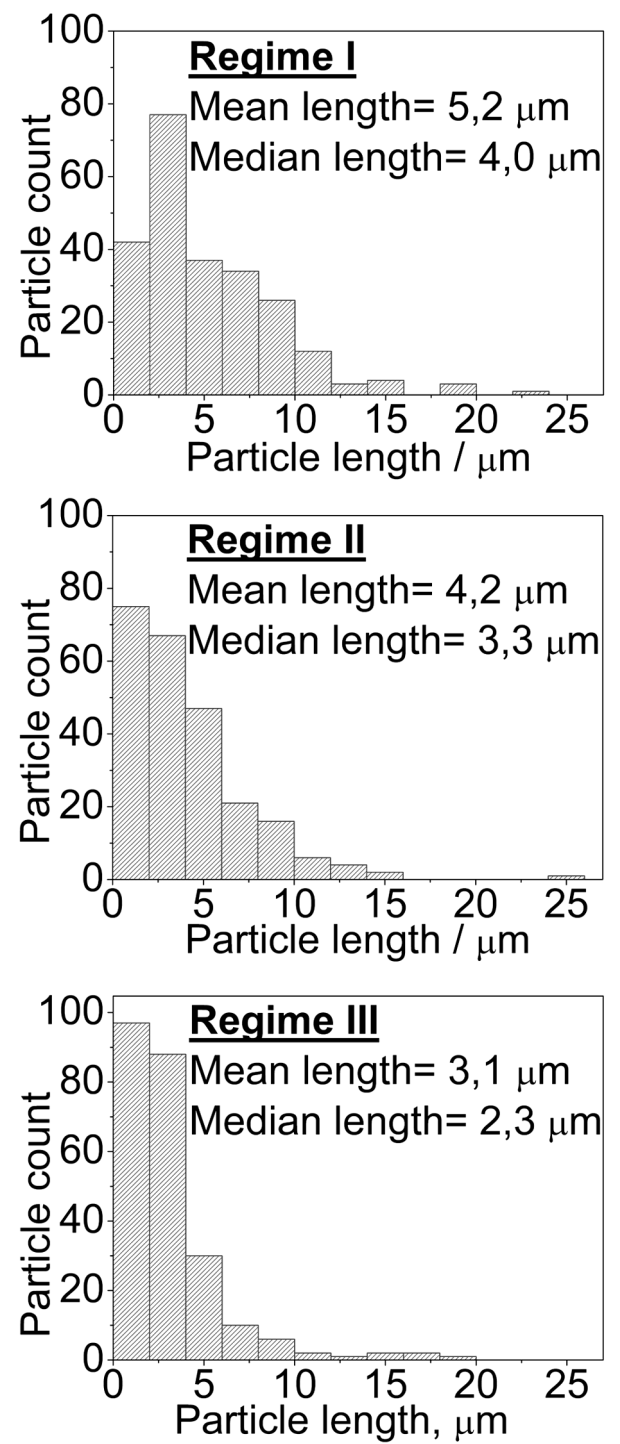

Figure 4: Size distribution (length) of fibrous $\mathrm{Mg}-\mathrm{Si}-\mathrm{Sr}$ constitutive particles. The total number of measured particles (240), was the same for each histogram.

Slika 4: Razporeditev velikosti (dolžine) vlaknastih Mg-Si-Sr delcev. Celotno število izmerjenih delcev (240), je bilo enako za vsak histogram
During homogenization at $460{ }^{\circ} \mathrm{C}$ (Regime I), growth and precipitation of $\mathrm{Mg}_{2} \mathrm{Si}$ phase took place at interfaces of the constitutive particles with the aluminum matrix (Figure 3a).

At homogenization temperatures above $500{ }^{\circ} \mathrm{C}$, $\mathrm{Mg}-\mathrm{Si}$ rich phases appear to dissolve as the fibers shortened (Figure 4). Clusters of the fibers delineating grain boundaries were still present after the homogenization at $520{ }^{\circ} \mathrm{C}$ (Regime II), but had almost completely vanished
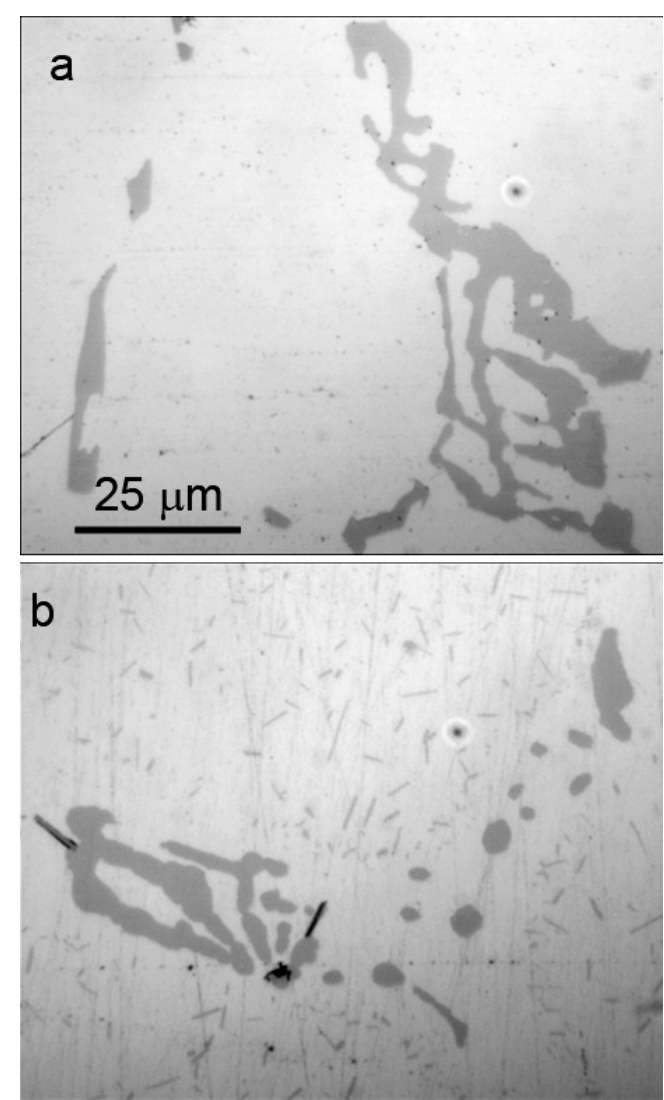

Figure 5: Light micrographs of the $\mathrm{Al}_{6}(\mathrm{Fe}, \mathrm{Mn})$ constitutive particles: a) $460{ }^{\circ} \mathrm{C}$ (Regime I), b) $550{ }^{\circ} \mathrm{C}$ (Regime III)

Slika 5: Svetlobna posnetka delcev $\mathrm{Al}_{6}(\mathrm{Fe}, \mathrm{Mn})$ : a) $460{ }^{\circ} \mathrm{C}$ (Regime I), b) $550{ }^{\circ} \mathrm{C}$ (Regime III) 
E. ROMHANJI et al.: HOMOGENIZATION OF AN Al-Mg ALLOY AND ALLIGATORING FAILURE
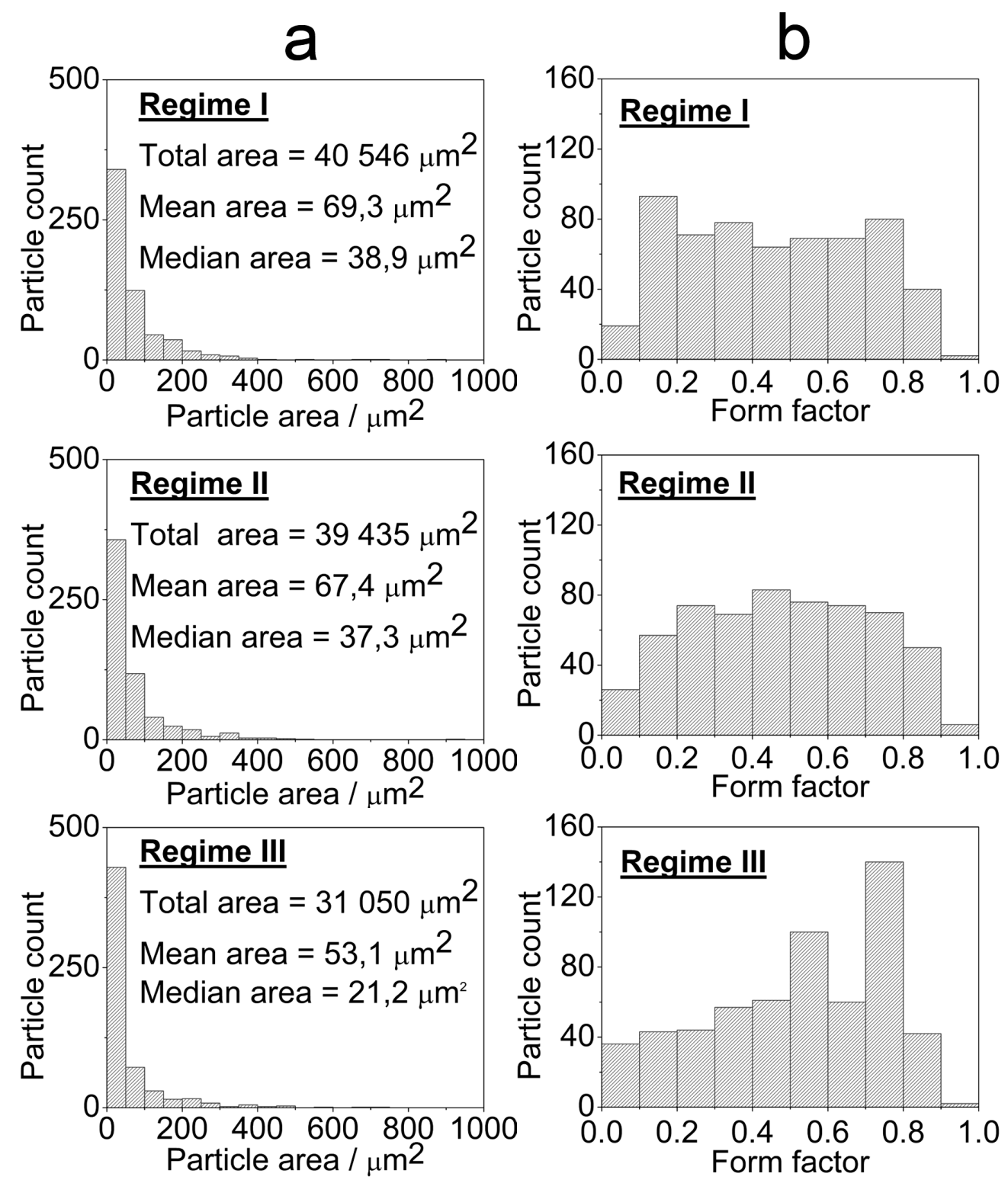

Figure 6: a) Size and b) form factor distribution of $\mathrm{Al}_{6}(\mathrm{Fe}, \mathrm{Mn})$ constitutive particles. The form factor is defined as $F=4 \pi \cdot$ Areal Perimeter $^{2}$ and reflects the particle shape. It is equal to 1 for a perfect circle and $<1$ for less regular shapes. The total number of measured particles (585), was the same for each histogram.

Slika 6: a) Velikost in b) faktor oblike razporeditve delcev. Faktor oblike je določen kot: $F=4 \pi \cdot$ površinalobseg $^{2}$ in odraža obliko delcev. Enak je 1 pri popolnoma okroglih delcih in je $<1$ pri manj pravilnih oblikah. Celotno število delcev (585), je bilo enako pri vseh histogramih.
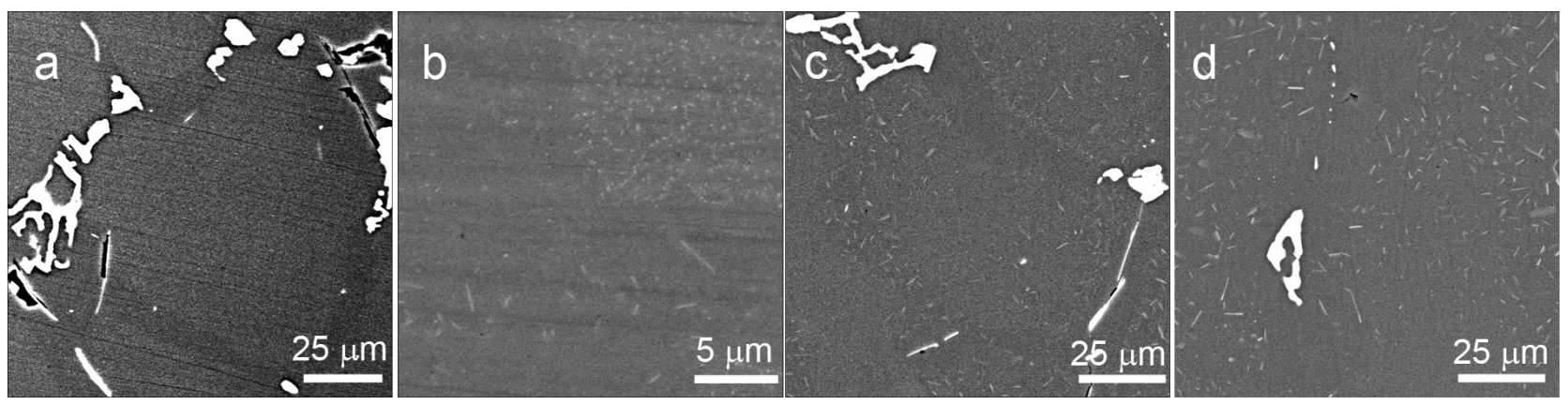

Figure 7: Backscattered SEM electron images of the microstructure after the homogenization anneal: a), b) $460{ }^{\circ} \mathrm{C}\left(\right.$ Regime I), c) $520{ }^{\circ} \mathrm{C}$ (Regime II) and d) $550{ }^{\circ} \mathrm{C}$ (Regime III)

Slika 7: SEM-posnetek, s povratno sipanimi elektroni, mikrostrukture po homogenizacijskem žarjenju: a), b) $460{ }^{\circ} \mathrm{C}\left(\operatorname{Režim~I),~c)~} 520{ }^{\circ} \mathrm{C}(\operatorname{Režim}\right.$ II) in d) $550{ }^{\circ} \mathrm{C}$ (Režim III) 
after homogenization at $550^{\circ} \mathrm{C}$ (Regime III) while the few remaining fibers were fragmented (Figure $3 \mathbf{b}$ ).

Annealing at higher temperatures (Regimes II and III) resulted in a partial dissolution and break down of the branches of the $\mathrm{Al}_{6}(\mathrm{Fe}, \mathrm{Mn})$ phase to more compact forms. The process was particularly advanced after the homogenization at $550{ }^{\circ} \mathrm{C}$ (Regime III) as can be seen from Figures 5 and $\mathbf{6}$.

Homogenization in a temperature range of $430-500{ }^{\circ} \mathrm{C}$ resulted in the precipitation of dispersoids in the dendrite cores (Figure 7a). Dendrite cores, with a high density of dispersoids, were surrounded by channels that were almost dispersoid free (Figure 7b). The width of the channels was in the range of 4-25 $\mu \mathrm{m}$.

Precipitation of coarser, rod- and plate-shaped Al-Mn-Fe particles took place during homogenization above $500{ }^{\circ} \mathrm{C}$. The precipitation occurred in the "precipitate free" channels formed during the first homogenization stage (annealing at $430{ }^{\circ} \mathrm{C}$ ) of Regimes II and III. After homogenization at $520^{\circ} \mathrm{C}$ (Regime II), the distinction between the regions was preserved (Figure 7c). The homogenization at $550{ }^{\circ} \mathrm{C}$ (Regime III) resulted in more uniform precipitation of coarser Al-Mn-Fe particles (Figure 7d).

Cooling down to the hot rolling onset temperature $\left(500{ }^{\circ} \mathrm{C}\right)$ caused further precipitation of dispersoids.

\section{DISCUSSION}

Non-heat treatable Al-Mg alloys contain two types of the particles, dispersoids and constitutive particles. The domination of ductile intergranular fracture in the alligatored plates points out the important role of constitutive particles in the failure. The tendency toward break-up of the constitutive particles is dependent on their morphology, i.e. complex and plate-like shapes are more prone to break-up than compact morphologies. ${ }^{7}$ In this study, the increase in the homogenization temperature led to changes in the constitutive particles that improved the ductility of the alloy. Thin plates of $\mathrm{Mg}-\mathrm{Si}-\mathrm{Sr}$ phase enveloping grains comprised the majority of the broken particles filling the dimples of the fractured plates which had been homogenized at $460{ }^{\circ} \mathrm{C}$ (Regime I). Their fraction decreased with a partial dissolution at $520{ }^{\circ} \mathrm{C}$ (Regime II). Homogenization at the highest temperature, $550{ }^{\circ} \mathrm{C}$, lead not only to almost complete dissolution of the $\mathrm{Mg}$-Si-Sr phase, but also to a change in the size and shape of the $\mathrm{Al}_{6}(\mathrm{Fe}, \mathrm{Mn})$ phase. $\mathrm{Al}_{6}(\mathrm{Fe}, \mathrm{Mn})$ transformed into more compact morphologies (Figures 5 and 6) resulting in an alloy with a good hot ductility that did not alligator during the hot deformation.

The primary function of the other type of particles in the alloy, dispersoids, is to limit grain growth during hot deformation. It is also known that they can contribute to the homogenization of $\operatorname{slip}^{8}$ and to reduction of the tendency toward intergranular embrittlement in $\mathrm{Al}-\mathrm{Mg}-\mathrm{Si}$ alloys. ${ }^{9}, 10$ However, in the studied alloy, homogenization below $500{ }^{\circ} \mathrm{C}$ resulted in non-uniform precipitation of the dispersoids and formation of broad precipitate free channels (Figure 7b). Such a microstructure strongly promoted localized slip. Impingement of the dislocation pile-ups at the grain boundaries or large constituent particles could create significant local stresses triggering grain boundary decohesion and embrittlement ${ }^{2}$ as well as break-up of the constituent particles (Figure 1). Absence of the brittle intergranular fracture in the plates homogenized at $520{ }^{\circ} \mathrm{C}$ (Regime II) $)^{2}$ indicates that precipitation of the rod-like dispersoids in the "precipitate free" channels decreased the extent of the slip localization that was the cause of the grain boundary decohesion.

Apparently, homogenization affected both types of particles present in the Al-5,1Mg-0,7Mn alloy. The increase in the homogenization temperature led to a more uniform distribution of the dispersoids and, hence, more uniform slip, as well as the reversal of the morphology of the constituent particles toward a more break-up resistant shape. The result was that the microstructure developed during the homogenization Regime III showed high resistance toward intergranular fracture and the absence of alligatoring.

\section{CONCLUSION}

The microstructure of the plates homogenized at $460{ }^{\circ} \mathrm{C}$ (Regime I) with well-defined precipitate rich and free zones promoted localized slip and inhomogeneous deformation resulting in brittle and ductile intergranular fracture. Precipitation of rod-like dispersoids into the precipitate free channels during homogenization at 520 ${ }^{\circ} \mathrm{C}$ (Regime II) contributed to the more uniform distribution of slip and only the ductile variant of intergranular fracture was observed. During homogenization at $550{ }^{\circ} \mathrm{C}$ (Regime III), fairly uniform distribution of the dispersoids, dissolution of $\mathrm{Mg}-\mathrm{Si}-\mathrm{Sr}$ phase and reversal of $\mathrm{Al}_{6}(\mathrm{Fe}, \mathrm{Mn})$ constituent particles toward more compact morphology contributed to the development of a ductile material that did not show a proclivity toward alligatoring.

\section{Acknowledgement}

This research was supported by Ministry of Education, Science and Technological Development, Republic of Serbia, and Impol-Seval Aluminium Rolling Mill, Sevojno, under contract grant TR 34018.

\section{REFERENCES}

${ }^{1}$ J. G. Lenard, Workability and Process Design in Rolling, In: G. Dieter, H. A. Kuhn, S. L. Semiatin (eds.), Handbook of Workability and Process Design, ASM International, Materials Park, Ohio, USA 2003, 258-277, doi:10.1361/hwpd2003p258

${ }^{2}$ E. Romhanji, T. Radetić, M. Popović, Homogenization of an Al-Mg alloy and alligatoring failure Part I: alloy ductility and fracture, Mater. Tehnol. 50 (2016) 3, 403-407, doi:10.17222/mit.2015.110 


\section{E. ROMHANJI et al.: HOMOGENIZATION OF AN Al-Mg ALLOY AND ALLIGATORING FAILURE}

${ }^{3}$ L. Xu, G. S. Daehn, Alligatoring and Damage in the cold rolling of spheroidized steels, Metallurgical and Materials Transactions A, 25 (1994) 3, 589-598, doi:10.1007/BF02651600

${ }^{4}$ H. Kim, M. Kang, S. Y. Shin, S. Lee, Alligatoring phenomenon occurring during hot rolling of free-machining steel wire rods, Materials Science and Engineering A, 568 (2013), 8-19, doi:10.1016/j.msea.2013.01.018

${ }^{5}$ M. R. Cappucci, An investigation of the workability of $\mathrm{Al}-8.5 \% \mathrm{Mg}$ alloys, Report MTL TR 89-33. U.S. Army Materials Technology Laboratory, Watertown, Massachusetts, http//www.dtic.mil/cgi-bin/ GetTRDoc?AD=ADA209451

${ }^{6}$ A. Halap, T. Radetić, M. Popović, E. Romhanji, Study of homogenization treatments of cast 5xxx series Al-Mg-Mn alloy modified with Zn, In: C. E. Suarez (Ed.), Light Metals 2012, John Wiley \& Sons, Inc., Hoboken, NJ, USA 2012, 387-392, doi:10.1002/ 9781118359259.ch65
${ }^{7}$ N. Moulin, E. Parra-Denis, D. Jeulin, C. Ducottet, A. Bigot, E. Boller, E. Maire, C. Barat, H. Klöcker, Constituent particle break-up during hot rolling of AA 5182, Advanced Engineering Materials, 12 (2010) 1-2, 20-29, doi:10.1002/adem.200900241

${ }^{8}$ J. M. Dowling, J. W. Martin, The influence of Mn additions on the deformation behaviour of Al-Mg-Si alloy, Acta Metallurgica, 24 (1976) 12, 1147-1153, doi:10.1016/00016160(76)90032-8

${ }^{9}$ K. C. Prince, J. W. Martin, The effect of dispersoids on micromechanisms of crack propagation, Acta Metallurgica, 27 (1979) 8, 1401-1408, doi:10.1016/0001-6160(79)90209-8

${ }^{10}$ J. D. Evensen, N. Ryum, J. D. Embury, The intergranular fracture of Al-Mg-Si alloys, Materials Science and Engineering, 18 (1975) 2, 221-229, doi:10.1016/0025-5416(75)90173-1 